Bayero Journal of Pure and Applied Sciences, 6(1): $79-81$

Received: April 2013

Accepted: June 2013

ISSN $2006-6996$

\title{
SERUM ANTIOXIDANT VITAMINS LEVELS IN CHILDREN WITH SICKLE CELL ANAEMIA IN SOKOTO, NORTH WESTERN NIGERIA
}

\author{
${ }^{1}$ Wali, U., ${ }^{1}$ Yeldu, M.H., ${ }^{1}$ Samaila, B, and ${ }^{2}$ Jiya, N. M. \\ ${ }^{1}$ Department of Chemical Pathology, Faculty of Medical Laboratory Science, \\ ${ }^{2}$ Department of Paediatrics, Usmanu Danfodiyo University Sokoto, Nigeria. \\ Correspondence author: Usmanwali90@yahoo.com
}

\begin{abstract}
Sickle cell anaemia is associated with elevated oxidative stress via increase generation of reactive oxygen species (ROS), and decline in antioxidant defences. Increased oxidative stress is thought to play a role in the development of sickle cell anaemic complications. In the current study, vitamins $A, C$, and $E$ levels were estimated in 35 sickle cell anaemics attending the Paediatric medical clinic of the Usmanu Danfodiyo University Teaching Hospital, Sokoto, Nigeria and the results compared with those of apparently healthy non-sickle cell anaemic volunteers of comparable age and social status. Serum levels of vitamin A, $C$, and $E$ were $31.06 \pm 2.97 \mu \mathrm{g} / \mathrm{dl}, 0.27 \pm 0.05 \mathrm{mg} / \mathrm{dl}, 0.20 \pm 0.01$ $\mathrm{mg} / \mathrm{dl}$ and $69.51 \pm 4.54 \mu \mathrm{g} / \mathrm{dl}, 0.77 \pm 0.10 \mathrm{mg} / \mathrm{dl}$ and $0.49 \pm 0.02 \mathrm{mg} / \mathrm{dl}$ in sickle cell anaemics and non- sickle cell anaemic subjects respectively. There was significantly $(P<0.05)$ decreased levels of antioxidant vitamins in sickle cell anaemic subjects. Age and gender did not have significant $(P>0.05)$ difference. The results suggest that sickle cell anaemics in the study area have low serum levels of antioxidant vitamins, an indication that the sickle cell anaemics are predisposed to increased oxidative onslaught. Keywords: Sickle cell anaemia, serum vitamins $A, C$, and $E$.
\end{abstract}

\section{INTRODUCTION}

Patients with sickle cell anaemia (SCA) suffer from many complications, including growth retardation, chronic haemolytic anaemia, recurrent and painful vaso-occlusive episodes, acute chest syndrome and impaired immune function (El-Hazmin, 1979). Although the exact reasons are not well established. Literature indicates that low levels of antioxidant vitamins, zinc and folic acid could be contributing factors (El-Hazmin, 1979; Powars, 1975). Sickle cell anaemia is a hereditary disorder caused by the substitution of valine for glutamic acid in the sixth position of the B-Chain of the haemoglobin (HbSS) with high potential for oxidative damage due to a chronic redox imbalance in red cells that often results in continuous generation of oxygen species and clinical manifestations of mild to severe haemolysis ( Rank et al., 1985). The production of reactive oxygen species (ROS) can be grossly amplified in response to a variety of pathophysiological conditions such as hypoxia, inflammation, infection, dehydration and deficiency in antioxidant vitamins (Bunn, 1997).

The deleterious effects of the excessive production of free radicals or reactive oxygen species can be prevented by the body's antioxidant defence mechanism which may include antioxidant vitamins ( $A, C$ and $E$ ) and enzymes such as superoxide dismutase, catalase, and glutathione peroxidase (Essien, 1995). Antioxidant vitamins help in neutralizing the effect of free radicals by mopping them off which further limit the sickle cell disease complications (Sies, 1997).

Sickle cell anaemics are under chronic oxidative stress induced by excessive production of free radicals from the sickle cell haemoglobin (Adam et al., 2001). This may overwhelm the normal antioxidant defences and deplete antioxidants including vitamins $A, C$ and $E$, and increases the frequency of sickling crises accompanied by tissue or organ damage (Adam et al., 2001). Sickle cell anaemia crises (haemolytic anaemia, jaundice, painful swelling of hands and feets and skeletal changes due to erythroid hyperplasia) is becoming rampant and is highly life threatening most especially in paediatric patients. It is expected that this study will stimulate interests, discussion and further studies on the role of antioxidant vitamins vis-à-vis complications of sickle cell anaemia. In this study serum vitamins $A, C$ and $\mathrm{E}$ were estimated in sickle cell anaemics and the results compared with those of apparently healthy non-sickle cell anaemics of comparable socioeconomic status. The correlation co-efficient between the serum levels of antioxidant vitamins $A, C$ and $E$ and the frequency of SCA crises were also determined.

\section{MATERIALS AND METHODS}

Participants: The subjects employed for this study were 35 sickle cell anaemic patients of both sexes who were attending the Paediatric medical clinic of the Usmanu Danfodiyo University Teaching Hospital, Sokoto, Nigeria. Also 35 apparently healthy participants of both sexes were recruited to serve as control. The consents of all the subjects were sought for and obtained. Ethical committee approval was also obtained for the research.

Blood samples: - Blood samples were collected by venipuncture and delivered into clean dry tubes and allowed to clot at room temperature. The samples were centrifuged at $3000 \mathrm{rpm}$ for 5 minutes using benchtop centrifuge and the serum separated and kept in labeled sample bottles at $\left(-20^{\circ} \mathrm{C}\right)$ until required. 
Reagents: All chemicals and reagents were of analytical grade and purchased from Sigma Chemical Company, USA.

Analytical methods: Serum vitamin A level was determined by method of Bassey et al. (1946), vitamin $C$ level was determined by method of Roe and Kuether (1943), and vitamin E level was determined by method of Neild and Pearson, (1967).

Statistical Analysis: Results are presented as mean \pm standard error of mean and separated on the basis of gender. Significant differences in mean at $5 \%$ level were determined using ANOVA. Serum levels of antioxidant vitamins were correlated with the sickle cell anaemic crises and correlation coefficients determined. SPSS Version 18 was used for the analysis.

\section{RESULTS}

The results of the current work showed significant difference $(P<0.05)$ between serum antioxidant vitamins of the sickle cell anaemic and non sickle cell anaemic participants (Table 1 ). Gender appears not to have significant $(P>0.05)$ effect on serum antioxidant vitamins.

Table 1: Serum Antioxidant vitamins of Sickle cell Anaemics (SCA) in Sokoto, Nigeria.

\begin{tabular}{|c|c|c|c|c|c|c|}
\hline \multicolumn{2}{|c|}{ Sickle Cell Anaemic } & \multicolumn{5}{|c|}{ Control } \\
\hline Parameters & Male & Female & Total & Male & Female & Total \\
\hline $\mathrm{N}$ & 20 & 15 & 35 & 20 & 15 & 35 \\
\hline Vit. A $(\mu \mathrm{g} / \mathrm{dl})$ & $44.46 \pm 8.20^{a}$ & $31.18 \pm 5.71^{b}$ & $31.11 \pm 2.97^{c}$ & $73.82 \pm 5.90^{a}$ & $63.76 \pm 7.10^{b}$ & $69.51 \pm 4.54^{c}$ \\
\hline Vit. C (mg/dl) & $0.33 \pm 0.08^{d}$ & $0.19 \pm 0.02^{\mathrm{e}}$ & $0.27 \pm 0.05^{f}$ & $0.73 \pm 0.11^{\mathrm{d}}$ & $0.84 \pm 0.20^{e}$ & $0.77 \pm 0.10^{f}$ \\
\hline Vit. E (mg/dl) & $0.19 \pm 0.01^{g}$ & $0.19 \pm 0.01^{\mathrm{h}}$ & $0.20 \pm 0.01^{\mathrm{i}}$ & $0.49 \pm 0.02^{g}$ & $0.49 \pm 0.03^{h}$ & $0.49 \pm 0.02^{i}$ \\
\hline
\end{tabular}

Values bearing same superscript differ significantly $(\mathrm{P}<0.05)$ using ANOVA.

Table 2: Age Distribution of Serum Antioxidant vitamins in Sickle cell Anaemic Children in Sokoto, Nigeria.

\begin{tabular}{|c|c|c|c|}
\hline Parameters & $\begin{array}{l}\text { Sickle Cell Anaemics* } \\
1-5 \text { Yrs }\end{array}$ & $6-10$ Yrs & $11-15$ Yrs \\
\hline Vit. A ( $\mu \mathrm{g} / \mathrm{dl})$ & $40.44 \pm 7.99$ & $39.30 \pm 9.71$ & $31.06 \pm 6.93$ \\
\hline Vit. C (mg/dl) & $0.30 \pm 0.08$ & $0.23 \pm 0.06$ & $0.21 \pm 0.07$ \\
\hline Vit. E (mg/dl) & $0.20 \pm 0.01$ & $0.18 \pm 0.01$ & $0.20 \pm 0.02$ \\
\hline
\end{tabular}

Values are means \pm SEM. Values show no significant different $(P .>0.05)$ using ANOVA.

Table 3 indicate significant $(\mathrm{P}<0.05)$ negative correlation coefficients between sickle cell anaemic crises and serum antioxidant vitamins.

Table 3: Correlation Coefficient ( $r$ ) of Sickle Cell Anaemic Crises with Serum Antioxidant Vitamins of Sickle Cell Anaemics in Sokoto, Nigeria.

\begin{tabular}{llll}
\hline Parameters & $\begin{array}{l}\text { Sickle Cell Anaemics } \\
\text { Male }\end{array}$ & Female & Total \\
\hline Vit. A $(\mu \mathrm{g} / \mathrm{dl})$ & -0.17 & -0.23 & -0.11 \\
Vit. C $(\mathrm{mg} / \mathrm{dl})$ & -0.10 & -0.07 & -0.19 \\
Vit. E $(\mathrm{mg} / \mathrm{dl})$ & -0.08 & -0.30 & -0.06 \\
\hline
\end{tabular}

All the serum antioxidant vitamins are significantly $(P<0.05)$ negatively correlated with sickle cell anaemia crises of the sickle cell anaemias.

\section{DISCUSSION}

Sickle cell anaemia is characterized by elevated oxidative stress via increased generation of reactive oxygen species (ROS), and decline in antioxidant defences (Ayyub et al., 2003). Increased oxidative stress is thought to play a role in the development of sickle cell anaemic complications (Ayyub et al., 2003). Antioxidant vitamins ( $A, C$ and $E$ ) are thought to be effective in increasing the activities of antioxidant defence enzymes, scavenging free radicals, preventing oxidative damage and thereby sparing lipid components of the cells against lipid peroxidation. Oxidative stress and hereditary disorder are suggested to be a potential contributor to the development of sickle cell anaemia and the associated complications (Zingg et al., 2000). This may be connected to the fact that the antioxidant status may be inadequate in sickle cell anaemic subjects. The metabolic significance of the evaluation of antioxidants in sickle cell anaemics is therefore of paramount importance.

The results of the current study indicate that serum vitamins $A, C$ and $E$ of the sickle cell anaemic subjects, in the study area were significantly $(P<0.05)$ lower than the values obtained for the non-sickle cell anaemic subjects. The results further reveal no significant difference in levels of antioxidant vitamins between male and female sickle cell anaemic subjects $(P>0.05)$.

The decreased levels of antioxidant vitamins are connected to increased oxidative stress in sickle cell anaemic patients, resulting in higher utilization of these vitamins and consequently leading to their deficiencies. Thus, increased intake of synthetic or natural antioxidant vitamins could help to avert sickle cell anaemic complications( Bunn, 1997). 
Since patients with sickle cell anaemia are under continuous oxidative stress due to sickle cell redox imbalance (Aslan et al., 2000), a deficiency in antioxidant vitamins may contribute to the severity of sickle cell manifestations, which could be aggrevated further by elevated copper, which is a well known prooxidant (Chan et al., 1999). The deficiency of vitamins also could account for some of the observed manifestations of sickle cell disease complications such as increased susceptibility to infection and haemolysis (Adelekan et al., 1989).

The negative correlation established between the serum levels of antioxidant vitamins and sickling crisis indicates that, the increases in the number of sickle cell crises are accompanied by a decrease in serum antioxidant vitamins. Sickle cell anaemic crises is associated with an over production of free radicals which are generated by the sickle cell haemoglobin (Habbel et al., 1997). This phenomenon may result into an increased utilization of the antioxidant vitamins

\section{REFERENCES}

Adam, R. J., Ohene-Frempong, K. and Wang, W. (2001): Sickle cell and the brain Haematology Am Soc. Haematol Educ Program, 1:31-46.

Adelekan, D. A., Thurham, D. I. and Adekile, A. D. (1989): Reduced Antioxidant capacity in Paediatric Patients with Homozygous Sickle cell disease Eur J. Clin Nutri. 43: 609 704.

Aslan, M., Thomley Brown, D. and Freeman, B.A. (2000): Reactive species in Sickle cell disease. Ann NY Acad Sci., 899:375-391.

Ayyub, J., Ahmed, M., Khan, M. A. and Khan, A.S. (2003): Naturally occurring antioxidant vitamin levels in patient with sickle cell anaemia. Vitamins patient, 15:21-25.

Bassey, D. A., Lowry, O. H., Brok, M. J., and Lopez, J. A. (1946): Determination of vitamin $A$. J. Bio Chem., 166:177.

Bunn, H. F. (1997): Pathogenesis and Treatment of Sickle cell disease. New Eng J. Med. 337: 762-769.

Chan,A.C.,Chow,C.K. and Chiu,D.(1999):Interaction of antioxidants and their implication in genetic anaemia.Proceed Society Exprem Biology Med.,222:274-282.
$A, C$ and $E$ which have been used in scavenging the excess amount of free radicals produced which therefore explain the depletion of the vitamins at period of sickling crises.

\section{CONCLUSION}

In conclusion, there is significant decrease in serum antioxidant vitamins in sickle cell anaemic subjects. Gender has no significant effect on antioxidant vitamins.Turkey-Kramer Multiple Comparison test (In Stat 3 Software, SanDiego,USA) was used. Further studies are needed to find out whether supplementation of antioxidant vitamins may ameliorate some sickle cell disease complications.

\section{Acknowledgements}

The authors knowledge the assistance of the Usmanu Danfodiyo University and Usmanu Danfodiyo University Teaching Hospital, Sokoto, Nigeria.

El-Hazmin, M.A.F. (1979): Nature of Sickle cell disease in the Arabian Peninsula. Human Genet, 52: 323-325.

Essien, E. V. (1995): Plasma levels of retinol, ascorbic acid and alpha tocopherol in Sickle cell anaemia. Cent Af J. Med., 41: 48-50.

Habbel, R. P., Eaton, I. W., Balasingam, M. and Steinberg, M. H. (1997): Spontaneous Oxygen Radical generation by Sickle erythrocytes J. Invest, 70: 1253-1259

Neild, J. B. and Pearson, W. N. (1967): Macro and Micro Method of determination of Serum vitamin E. Using Triflouro acetic acid. Nutr., 79:10-20.

Powars, D. R. (1975): Natural History of Sickle cell disease the first ten years. Sem Hemat., 12:48-50.

Rank, B. H., Carisson, J. and Habbel, R.P. (1985): Abnormal redox status of membrane protein thiols in Sickle erythrocytes J. Clin. Investig., 75: 1531-1537.

Roe, J. H., and Kuether, C. A. (1943): Determination Off vitamin C. J. Biol. Chem., 147: 399.

Sies, H. (1997): Oxidative Stress Oxidants and antioxidants. Exp. Physiol., 822:291-295.

Zingg, J. M., Ricciareili, R., and Azzl, A. (2000): Scavenger Receptor and Modified Lipoproteins Fetal Attractions IUBMB Life, 49: 397-403. 